\title{
Effect of urban geometry and green area on the formation of the urban heat island in Baghdad city
}

\author{
Younis Mohammed ${ }^{1}$ and Aws Salman ${ }^{1, *}$ \\ ${ }^{1}$ Department of Architecture Engineering, University of Technology, Baghdad, Iraq
}

\begin{abstract}
With the growth of cities, the ambient air temperatures (Ta) inside the urban areas are expected to be higher compared to the surrounding rural areas, creating urban heat island (UHI) phenomenon. The city of Baghdad is an example of a hot dry climate cities and during summer, the UHI intensity is significantly affected by the extreme direct solar radiation and leads to outdoor thermal discomfort. Also it causes an increase in energy consumption and air pollution. This research work focuses on the effect of urban geometry and green area in the formation of heat island through a study of two different fabrics of residential neighbourhoods. The height to width ratio $(\mathrm{H} / \mathrm{W})$ and vegetation are adopted while the materials of buildings were unified in all study cases. Three-dimensional numerical software Envi-met 4.1 was utilized to analyze and assess the studied parameters including: ambient air temperature (Ta), street surface temperature (Ts) and mean radiant temperature (Tmrt). This study has given a better understanding of the role of urban geometry and green area on forming the UHI that influence on the microclimatic conditions in hot dry climate of the city of Baghdad. So that helped to generate guidelines of urban design and planning practices for a better thermal performance in hot and dry cities.
\end{abstract}

Day after day the cities growth and became bigger and bigger and the ambient air temperatures $\left(T_{a}\right)$ inside the urban cores are expected to be higher than that in their surrounding countryside, creating urban heat island (UHI) phenomenon[1-4]. The bad effect of the urban heat island (UHI) phenomenon, particularly on energy use, human health and air quality as well as its significant effect on human comfort, many researchers are focusing on the possible strategies for mitigating UHI and many of them are interested to investigate at the scale of neighbours [4-7].

There are a number of mitigation strategies. One of them is related with the use of trees or vegetation in urban areas. Vegetation can contribute significantly to park cool island (PCI) influence and consequently can reduce air temperature up to 3 to $4^{\circ} \mathrm{C}$ in hot summer periods [810]. Vegetation can make $T_{a}$ reduction possible through several mechanisms. First, higher albedo value compared with construction materials such as asphalt. Second, through evaporation and transpiration. Third, with lower specific heat capacity greeneries absorb less heat. Finally, with shading, leaves and branches reduce the amount of solar radiation that reaches the urban surfaces below the canopy layer [9-15].

The effect of vegetation on the conditions of microclimate and thermal comfort can be evaluated by computer simulation software programs for the environment. This helped to understand many of the current environmental problems where it let to quantify the influences of zone changes (land coverage) on microclimate conditions and human thermal comfort, through microclimate models such as Envi-met [5], [16].

Also, this study is highlight on the role of urban geometry as a potential mitigation strategy [8]. Investigation that studies the impact of urban configurations variables in hot dry climate (density, urban canyons, and orientation) in forming the UHI effect in cities is still required [2], [17]-[20]. Huge quantities of solar radiations are mainly stored and reradiated in urban areas due to massive construction material and canyon effect, which is more relevant in case of taller buildings [20]. Density of buildings can significantly impact the UHI by reducing or increasing the areas of exposed surfaces. The geometry of urban canyons can influence the speed of airflow for natural ventilation system (NVS) and also can shape shaded paths for pedestrians. This geometry is expressed by the ratio of building height $(\mathrm{H})$ and street width $(\mathrm{H} / \mathrm{W})$, or the aspect ratio [16], [20].

The current study focuses on the city of Baghdad, the largest urban area in Iraq [21]. This city is characterized by a variety of urban forms: These urban patterns include attached and detached. The patterns include the areas that have developed primarily in the modern suburbs in the middle of the 20th century; and the areas that have been shaped primarily in the last quarter of the 20 century and are distributed in the city edges. These patterns have been developed on the basis of modern planning practices. These practices were imported from western contexts, where cold and

\footnotetext{
*Corresponding author:aws_m_s2007@yahoo.com
} 
moderate climates are prevalent without consideration to extreme local climates in hot and arid regions [20].

It was decided to investigate how urban form and green area influences the quality of outdoor spaces of two common residential neighbourhoods in the city of Baghdad. A comparison have been made to find out the impact of these UHI mitigation strategies on thermal comfort in the selected area.

The aim of the study presented is to investigate the influence of several variables, which co-cause the Urban Heat Island effect, on temperature distribution $\left(T_{a}, T_{s}\right.$, and $T_{m r t}$ ) and on outdoor thermal comfort. In particular, it tries to provide a better understanding of how the geometry of the urban canyon and vegetation contributes to the formation of the UHI. A simulation tool, ENVImet Version 4.1, is used to forecast the microclimatic changes within urban environment.

\section{Methodology}

\subsection{Selected urban areas}

Two locations of the city were selected to represent the attached, and detached urban configurations. The case studies represent a variety of urban forms with regards to the density, urban canyons, and orientation Fig. (1). The key determinant factor of choosing such configurations is that they all represent urbanized areas and vary significantly in their design, layout, and characteristics. First, the modern attached case includes rectangular long urban blocks, gridded street systems, and attached buildings from three sides and is laid out perpendicularly on the streets. Second, even though it is derived from the previous pattern, the modern detached

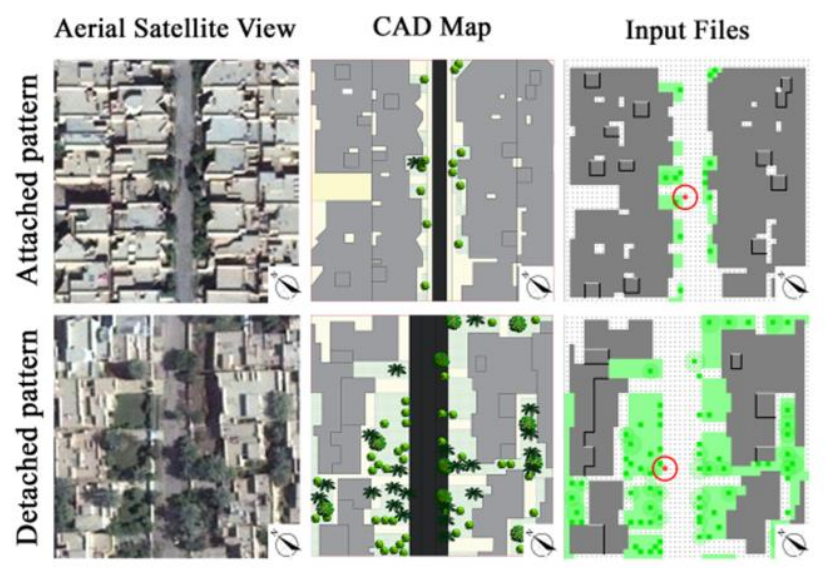

Fig. 1. Representation of the selected two study cases of urban form in the city of Baghdad. Red point in (Input File) column represented the measurement point in each area.

case has wider streets aligned with detached buildings that occupy small footprints and typically are placed in the middle of plots. To establish comparable cases and to assure that the urban configuration and vegetation are the dominant factor in the analysis, streets in all cases are oriented northeast-southwest and materials for all buildings surfaces are identical.

Building height and the land use in each area are shown in Table 1. Also, this table shows the building surface cover in terms of building density and average height. The two selected location covering an area of $100 \times 100 \mathrm{~m}$ were used for the investigation.

Table 1. Building height and land use properties in each area.

\begin{tabular}{|c|c|c|c|}
\hline & & Detached & Attached \\
\hline \multirow{4}{*}{$\begin{array}{c}\text { Land } \\
\text { surface } \\
\text { cover (\%) }\end{array}$} & $\begin{array}{c}\text { Building } \\
\text { asphalt }\end{array}$ & 39.75 & 75.6 \\
\cline { 2 - 4 } & Pavement & 12.85 & 6 \\
\cline { 2 - 4 } & Soil & 0 & 2.9 \\
\cline { 2 - 4 } & Grass & 31.4 & 6 \\
\hline \multirow{2}{*}{$\begin{array}{c}\text { Building } \\
\text { height (m) }\end{array}$} & $\begin{array}{c}\text { Elevations } \\
\text { height }\end{array}$ & 3 or 6 & 6 \\
\cline { 2 - 4 } & $\begin{array}{c}\text { Highest } \\
\text { point }\end{array}$ & 8 & 8 \\
\hline
\end{tabular}

\subsection{Urban environmental simulation}

With the aim to forecast the microclimatic changes within urban environment, a simulation tool, ENVI-met Version 4.1, was used. ENVI-met, a three-dimensional computer software that simulates micro-scale conditions in urban environments. ENVI-met is designed to simulate the surface-plant-air interactions. Typically, Envi-met model has spatial resolution from $0.5 \mathrm{~m}$ to $10 \mathrm{~m}$, and a temporal resolution of 10 seconds. The best time to start a simulation is at night, so that the simulation can follow the solar radiation increase during the day. In hot and dry climate simulation was carried out for more than 24 hours and results are taken after the first 24 hours. This gives more accurate results. A detailed description of microclimate model Envi-met and further information can be accessed through its official website [22]-[25]. Envi-met can be used to evaluate several aspects of urban canyons and the effects of vegetation on outdoor comfort and urban heat island mitigation [26].

In this research, typical summer day are selected for simulation. (Table 2) illustrates the input data for July 15th, 2015, which has the highest recorded air temperature in the city of Baghdad. ENVI-met 4.1 is using to evaluate the $T_{a}, T_{s}$, and $T_{m r t}$ of the two selected cases. In order to compare the effects of different scenarios in the two urban locations, three models for each location were considered (Table 3):

- Base model: it represents the existing current location;

- No green model: it represents the existing current location without green area and vegetation;

- Green model: it represents the existing current location with a vegetation coverage higher than in the base model. 
Table 2. Details of initialization input parameters for the simulations in ENVI-met.

\begin{tabular}{lcl}
\hline Data Type & \multicolumn{1}{c}{ Parameter } & \multicolumn{1}{c}{ Value } \\
\hline General & Date of start the simulation & $\begin{array}{l}\text { 15 July } \\
2015\end{array}$ \\
& Simulation starting time & 5:00 A.M. \\
& Simulation duration & 44 hours
\end{tabular}

Initial data Wind Speed in $10 \mathrm{~m}$ ab. $\quad 2.0$

Ground $[\mathrm{m} / \mathrm{s}]$ Wind

Direction

(0:N..90:E..180:S..270:W..)

Roughness Length $\mathrm{z} 0$ at

Reference Point [m] Specific

Humidity in $2500 \mathrm{~m}$ [g

Water $/ \mathrm{kg}$ air] Factor of

shortwave adjustment $(0.5$ to

1.5)

Initial Temperature

Atmosphere [K]

Soil data

Initial temperature/RH Upper

Layer $(0-20 \mathrm{~cm})$

Initial temperature/RH

Middle Layer $(20-50 \mathrm{~cm})$

Initial temperature/RH Deep

Layer (below $50 \mathrm{~cm}$ )

Building

Material

Properties

Albedo (\%)

0.3

1.3

Thermal conductivity

(W/m.K)

Surface

Material

\begin{tabular}{ll}
\hline & Asphalt \\
& Street: 0.2 \\
& \\
Albedo (\%) & concrete \\
& pavement \\
& gray: 0.5
\end{tabular}

Roof:

1.9

In this study, each case was modelled with a domain dimension of $50 \times 50 \times 20$ and a resolution of $2 \mathrm{~m} \times 2 \mathrm{~m} \times$ $1 \mathrm{~m}$, making a total model area of $100 \mathrm{~m} \times 100 \mathrm{~m} \times 20 \mathrm{~m}$. Six different scenarios were created viz. DN, DB, DG, $\mathrm{AN}, \mathrm{AB}$ and $\mathrm{AG}$. The first letter represents detached (D) or attached (A) pattern while the second letter represents the selected scenario which is no green $(\mathrm{N})$, base $(\mathrm{B})$ or green $(\mathrm{G})$. Table 3 shows the number of trees and the type of trees in each scenario. Big tree have a height of 7 meters and a width of 9 meters, small tree have a height of 5 meters and a width of 3 meters and Plame have a height of 8 meters and a width of 6 meters.

Table 3. Details of number and type of trees in each scenario.

\begin{tabular}{|c|c|c|c|}
\hline Scenarios & Big tree & Small tree & Plame \\
\hline DN & 0 & 0 & 0 \\
\hline DB & 10 & 39 & 21 \\
\hline DG & 21 & 50 & 31 \\
\hline AN & 0 & 0 & 0 \\
\hline AB & 0 & 13 & 1 \\
\hline AG & 0 & 60 & 1 \\
\hline
\end{tabular}

\section{Results and discussion}

\subsection{Air temperature $\left(T_{a}\right)$}

In the detached pattern (Fig2), the hottest values of $T_{a}$ were found at 3:00 $\mathrm{PM}$ which were $50.0^{\circ} \mathrm{C}, 49.9^{\circ} \mathrm{C}$ and $49.65^{\circ} \mathrm{C}$ in no green, base and green scenarios, respectively. The lowest values of $T_{a}$ were found at 5:00 AM which were $35.3^{\circ} \mathrm{C}, 34.7^{\circ} \mathrm{C}$ and $34.67^{\circ} \mathrm{C}$ in no green, base and green scenarios, respectively. The average values of $T_{a}$ were of $42.9^{\circ} \mathrm{C} 42.6^{\circ} \mathrm{C}$ and $42.4^{\circ} \mathrm{C}$ in no green, base and green scenarios, respectively. During daytime periods, the difference in average was $0.18^{\circ} \mathrm{C}$ between no green and base scenarios while it was $0.46^{\circ} \mathrm{C}$ between no green and green scenarios. During night time periods, the maximum difference in $T_{a}$ was found in 5:00 AM which was $0.6^{\circ} \mathrm{C}$ between no green and base scenarios while its $0.63^{\circ} \mathrm{C}$ between no green and green scenarios. The average difference at night time periods was $0.45^{\circ} \mathrm{C}$ between no green and base scenarios

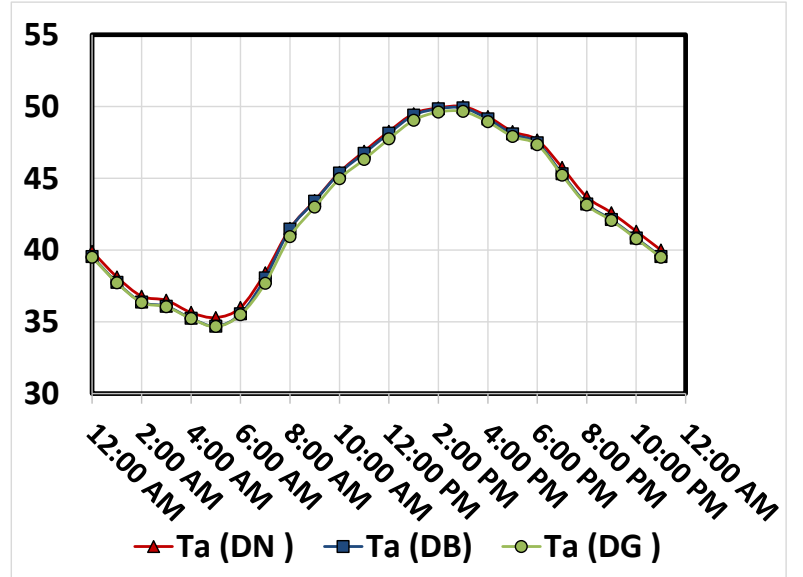


Fig. 2. Variations of $T_{a}$ during the day at pedestrian walkway of detached pattern at a height of $1.5 \mathrm{~m}$ from the ground. while it was $0.46^{\circ} \mathrm{C}$ between no green and green scenarios.

The results have shown that the green area is more effective during night time periods. The reason for this is that the larger area of asphalt and cement surfaces in no green scenario stores more heat during daytime and radiate at night time which causes higher values of $T_{a}$ during night time periods. However, green area effects on $T_{a}$ values was small.

In the attached pattern (Fig 3), the hottest values of $T_{a}$ were found at $3: 00 \mathrm{PM}$ which were $49.6^{\circ} \mathrm{C}, 49.5^{\circ} \mathrm{C}$ and $49.5^{\circ} \mathrm{C}$ in no green, base and green scenarios, respectively. The lowest values of $T_{a}$ were found at 5:00 AM which were $35.3^{\circ} \mathrm{C}, 35.2^{\circ} \mathrm{C}$ and $35.1^{\circ} \mathrm{C}$ in no green, base and green scenarios, respectively. The average values of $T_{a}$ were $42.8^{\circ} \mathrm{C}, 42.7^{\circ} \mathrm{C}$ and $42.6^{\circ} \mathrm{C}$ in no green, base and green scenarios, respectively. During daytime periods, the difference in average was $0.07^{\circ} \mathrm{C}$ between no green and base scenarios while its $0.18^{\circ} \mathrm{C}$ between no green and green scenarios. During nighttime periods, the maximum difference in $T_{a}$ was found in 5:00 AM which was $0.1^{\circ} \mathrm{C}$ between no green and base scenarios while it was $0.2^{\circ} \mathrm{C}$ between no green and green scenarios. The difference on an average during nighttime periods was $0.08^{\circ} \mathrm{C}$ between no green and base scenarios while its $0.15^{\circ} \mathrm{C}$ between no green and green scenarios.

The results have shown that the green area has low effects during daytime and nighttime periods. The reason for this is the small area of vegetation and green surfaces in both base and green scenarios.

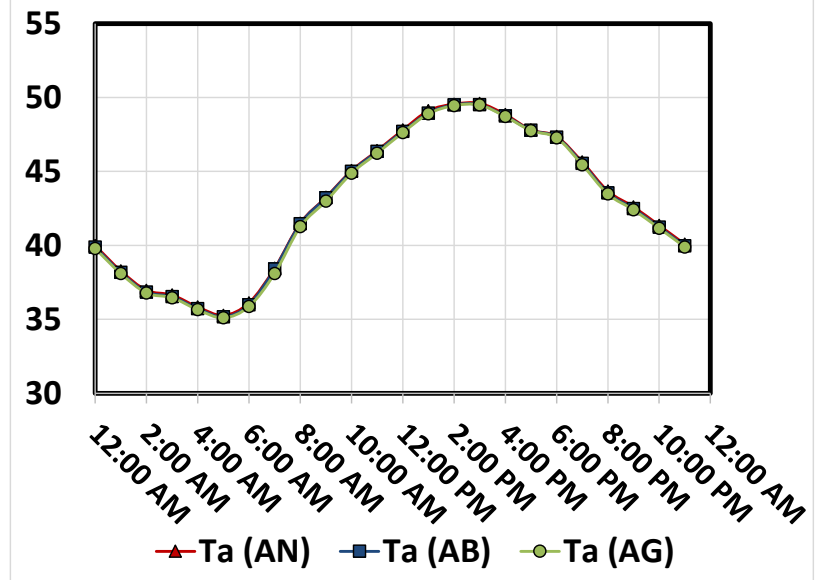

Fig. 3. Variations of $T_{a}$ during the day at pedestrian walkway of attached pattern at a height of $1.5 \mathrm{~m}$ from the ground.

Figure 4 compares between average values of $T_{a}$ in different scenarios. In no green scenarios, the results have shown that the detached pattern has higher value of $T_{a}$ than attached by $0.18^{\circ} \mathrm{C}$. The maximum difference in $T_{a}$ during daytime periods was found in 3:00 PM which was $0.4^{\circ} \mathrm{C}$. The difference in average during daytime periods was $0.3^{\circ} \mathrm{C}$. During nighttime periods the detached pattern have lower value of $T_{a}$ than attached by $0.07^{\circ} \mathrm{C}$ in average. It is obvious that the $\mathrm{H} / \mathrm{W}$ ratio in the shallow detached street enhances the performance of dissipating and cooling by winds and breezes during night, while the $\mathrm{H} / \mathrm{W}$ ratio in the attached street helps to minimize the accessibility of solar radiation into the canyons during the daytime and maximize the shaded areas, which help the surfaces to remain cool.
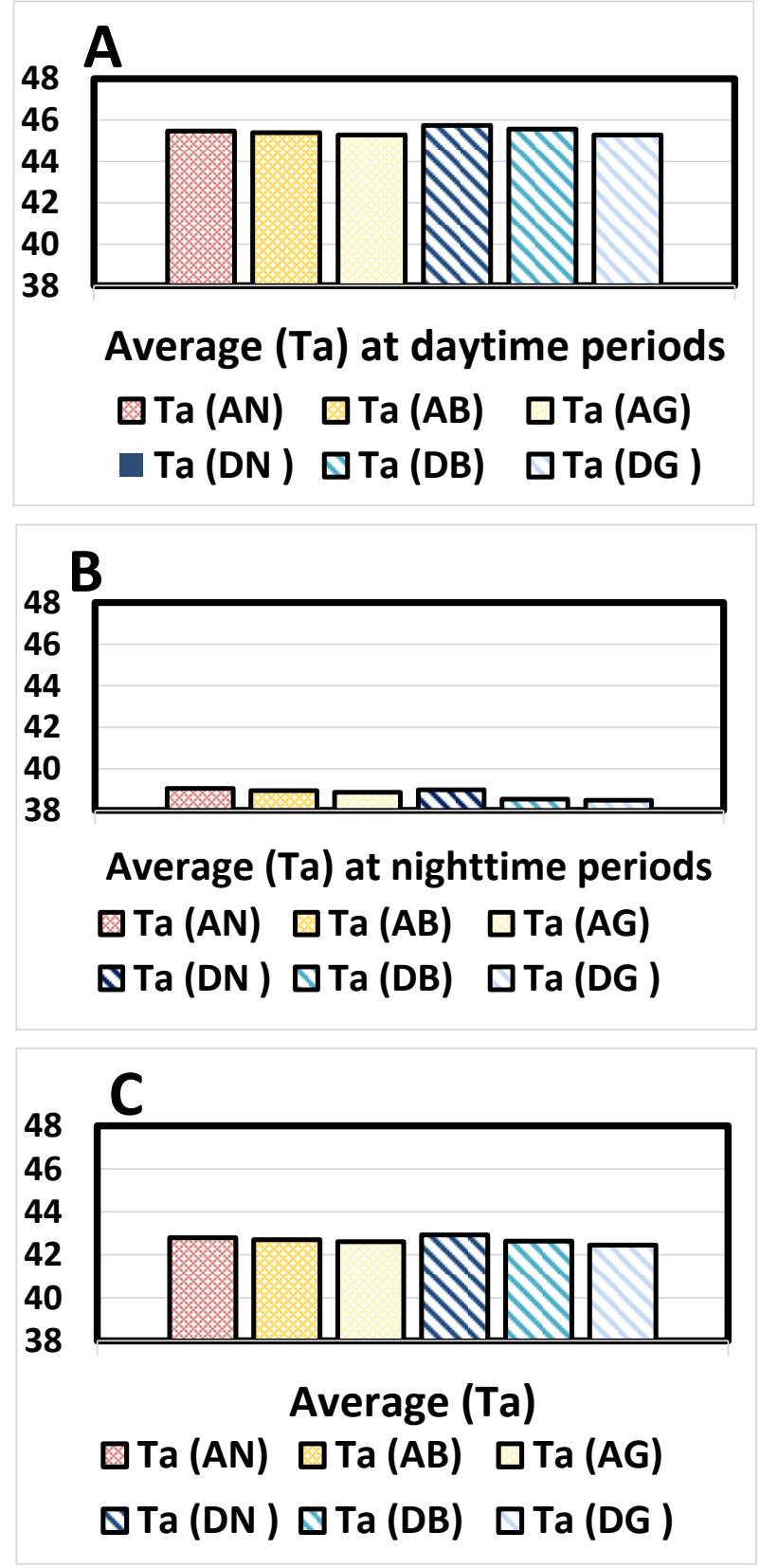

Fig. 4. Average of $T_{a}$ at pedestrian walkway of each street at a height of $1.5 \mathrm{~m}$ from the ground. A) Represent average of total $T_{a}$ during daytime periods; B) represent average of $T_{a}$ during night time periods; C) represent average of total $T_{a}$ during the daytime and night time periods.

In base scenarios, the results have shown that the 
detached pattern have higher value of $T_{a}$ during daytime periods. The maximum difference in $T_{a}$ during daytime periods was found at 3:00 $\mathrm{PM}$ which was $0.4^{\circ} \mathrm{C}$. The difference in average during daytime periods was $0.16^{\circ} \mathrm{C}$. During nighttime periods the detached pattern have lower value of $T_{a}$ than attached by $0.4^{\circ} \mathrm{C}$ in average. The maximum difference in $T_{a}$ during nighttime periods was found at 5:00 AM which was $0.47^{\circ} \mathrm{C}$. The $\mathrm{H} / \mathrm{W}$ ratio in the attached street with trees helps to minimize the accessibility of solar radiation into the pedestrian walkway during the daytime and maximize the shaded areas, which helped the surfaces to remain cool. In the detached pattern the buildings play a lesser role in the shading because it is far in the distance from the pedestrian walkway. During nighttime, the large green area in the detached pattern compared with the attached pattern as well as the wind plays important role in reduce $T_{a}$.

In green scenarios, the results have shown that the two areas have almost equal value of $T_{a}$ during daytime periods. The maximum difference in $T_{a}$ during daytime periods was found in 4:00 $\mathrm{PM}$ which was $0.01{ }^{\circ} \mathrm{C}$. During nighttime periods the detached pattern have lower value of $T_{a}$ than attached by $0.4^{\circ} \mathrm{C}$ in average. Wider and denser green spaces in the detached pattern contribute more to reducing $T_{a}$, however, the attached pattern needs fewer trees to achieve almost equal value of $T_{a}$ during daytime periods compare with detached pattern.

The best scenario of $T_{a}$ in all cases was found in detached pattern with green scenario while the worst scenario of $T_{a}$ in all cases was found in detached pattern with no green scenario. That show us how vegetation densities can affect the microclimate conditions and contribute to its improvement. The results also have shown that attached pattern have more balanced value of $T_{a}$ and needs fewer trees to achieve almost equal value of $T_{a}$ during daytime periods compare with detached pattern.

\subsection{Ground surface temperature $\left(T_{s}\right)$}

In the detached pattern (Fig 5), the hottest values of $T_{s}$ was found at $3: 00 \mathrm{PM}$ which were $62.1^{\circ} \mathrm{C}, 58.5^{\circ} \mathrm{C}$ and $51.1^{\circ} \mathrm{C}$ in no green, base and green scenarios, respectively. The lowest values of $T_{s}$ were found at 5:00 AM which were $35.7^{\circ} \mathrm{C}, 35.8^{\circ} \mathrm{C}$ and $35.9^{\circ} \mathrm{C}$ in no green, base and green scenarios, respectively. The average values of $T_{s}$ were $48.3^{\circ} \mathrm{C}, 47.5^{\circ} \mathrm{C}$ and $43.9^{\circ} \mathrm{C}$ in no green, base and green scenarios, respectively. During daytime periods, the difference in average was $1.4^{\circ} \mathrm{C}$ between no green and base scenarios while it was $7.3^{\circ} \mathrm{C}$ between no green and green scenarios. During nighttime periods, the maximum difference in $T_{s}$ was found in 5:00 AM which was $0.1^{\circ} \mathrm{C}$ between no green and base scenarios while it was $0.2^{\circ} \mathrm{C}$ between no green and green scenarios. The difference in average during nighttime periods was $0.05^{\circ} \mathrm{C}$ between no green and base scenarios while it was $0.4^{\circ} \mathrm{C}$ between no green and green

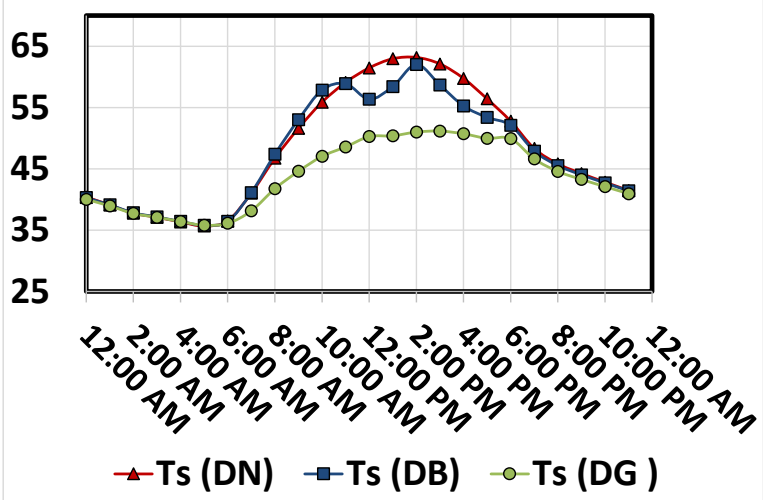

scenarios. The results have shown that the green area is more effective during daytime periods. The reason for this is the shade from trees which increases with

Fig. 5. Variations of $T_{s}$ during the day at pedestrian walkway of detached pattern.

increasing tree density and causes a reduction in values of $T_{s}$.

In the attached pattern (Fig. 6), the hottest values of $T_{s}$ were found at $3: 00 \mathrm{PM}$ which were $56.0^{\circ} \mathrm{C}, 53.0^{\circ} \mathrm{C}$ and $53.6^{\circ} \mathrm{C}$ in no green, base and green scenarios, respectively. The lowest values of $T_{s}$ were found at 5:00 AM which were $30.6^{\circ} \mathrm{C}, 30.6^{\circ} \mathrm{C}$ and $30.9^{\circ} \mathrm{C}$ in no green, base and green scenarios, respectively. The average values of $T_{s}$ were $45.2^{\circ} \mathrm{C}, 43.5^{\circ} \mathrm{C}$ and $43.0^{\circ} \mathrm{C}$ in no green, base and green scenarios, respectively. During daytime periods, the difference in average was $2.7^{\circ} \mathrm{C}$ between no green and base scenarios while it was $3.6^{\circ} \mathrm{C}$ between no green and green scenarios. During nighttime periods, the difference in $T_{s}$ values were small and it's ineffective.

The results have shown that the green area is more effective during daytime periods. The reason for this is the shade from trees. This effectiveness is increases with increasing tree density and causes a reduction in values of $T_{s}$.

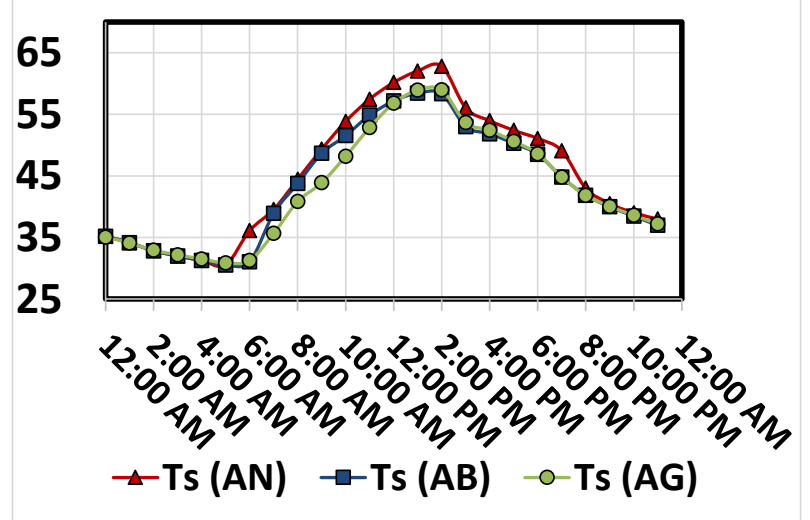

Fig. 6. Variations of $T_{s}$ during the day at pedestrian walkway of attached pattern. 
Figure 7 compares the average values of $T_{s}$ in different scenarios. In no green scenarios, the results have shown that the detached pattern have higher value of $T_{s}$ than attached by an average of $3.0^{\circ} \mathrm{C}$. The maximum difference in $T_{s}$ during daytime periods was found at 3:00 PM which was $6.1^{\circ} \mathrm{C}$. The difference in average during daytime periods was $2.1^{\circ} \mathrm{C}$. During nighttime periods, the Attached pattern has lower value of $T_{s}$ than Detached by an average of $4.4^{\circ} \mathrm{C}$. The reason behind it may be the nearly building and trees in Attached pattern were provided more shade on walkways and lead to reduce $T_{s}$ in it.

In base scenarios, the results have shown that the detached pattern have higher value of $T_{s}$ than attached by $3.7^{\circ} \mathrm{C}$ on an average. This is more pronounced during the nighttime where the difference in $T_{s}$ is $4.7^{\circ} \mathrm{C}$ while it was $3.0^{\circ} \mathrm{C}$ during daytime. The reason behind it may be the nearly building and trees in Attached pattern were provided more shade on walkways and lead to reduce $T_{s}$ in it.

In green scenarios, the results have shown that the detached pattern has higher value of $T_{s}$ than attached by $0.9^{\circ} \mathrm{C}$ on an average. During daytime the detached pattern has lower value of $T_{s}$. The maximum difference in $T_{s}$ during daytime periods was found at 2:00 PM which was $7.0^{\circ} \mathrm{C}$. The difference in average during daytime periods was $1.5^{\circ} \mathrm{C}$. The reason of that was the shade from trees which has higher density in the detached pedestrian walkway. During nighttime periods the detached pattern has higher value of $T_{s}$ than attached. The maximum difference in $T_{s}$ during nighttime periods was found at 5:00 $\mathrm{AM}$ which was $4.9^{\circ} \mathrm{C}$. The difference in average during nighttime periods was $4.2^{\circ} \mathrm{C}$. This may be because of two reasons: first, the quality and albedo of material in pedestrian walkway and second, the wind speed. The material in detached pedestrian walkway is asphalt which has lower albedo than cement surfaces in attached pedestrian walkway. Asphalt stores more heat during daytime and radiate during nighttime. Wind speed can also be less due to high density of trees in detached pedestrian walkway. Less wind and breeze leading to slower $T_{s}$ loss.

The best scenario of $T_{s}$ in all cases was found in attached area with green scenario while the worst scenario of $T_{s}$ in all cases was found in detached pattern with no green scenario. The trees cover and the material played an important role in influencing the value of $T_{s}$.

\subsection{Mean radiant temperature ( $\left.T_{m r t}\right)$}

In the detached pattern (Fig. 8), the hottest values of $T_{m r t}$ was found at 3:00 PM which was $88.4^{\circ} \mathrm{C}, 69.2^{\circ} \mathrm{C}$ and $61.2^{\circ} \mathrm{C}$ in no green, base and green scenarios, respectively. The lowest values of $T_{m r t}$ was found at 5:00 AM which was $28.6^{\circ} \mathrm{C}, 29.8^{\circ} \mathrm{C}$ and $30.7^{\circ} \mathrm{C}$ in no green, base and green scenarios, respectively. The average values of $T_{m r t}$ was $58.0^{\circ} \mathrm{C}, 52.5^{\circ} \mathrm{C}$ and $46.0^{\circ} \mathrm{C}$ in no green, base and green scenarios, respectively. During daytime periods, the difference in average was $9.9^{\circ} \mathrm{C}$ between no green and base scenarios while it was $21.3^{\circ} \mathrm{C}$ between no green and green scenarios. During nighttime periods, the maximum difference in $T_{m r t}$ was found at 5:00 AM which was $1.2^{\circ} \mathrm{C}$ between no green and base

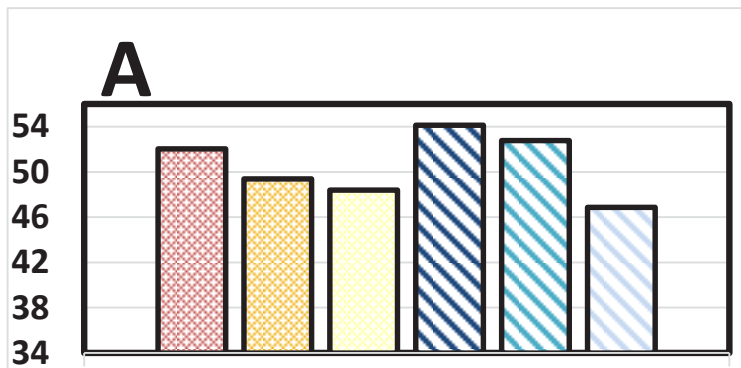

Average Ts at daytime periods
⿴囗十 (AN) $\square$ Ts (AB) $\square \mathrm{Ts}(\mathrm{AG})$
$\nabla T s$ (DN) $\nabla T s$ (DB) $\square T s$ (DG )

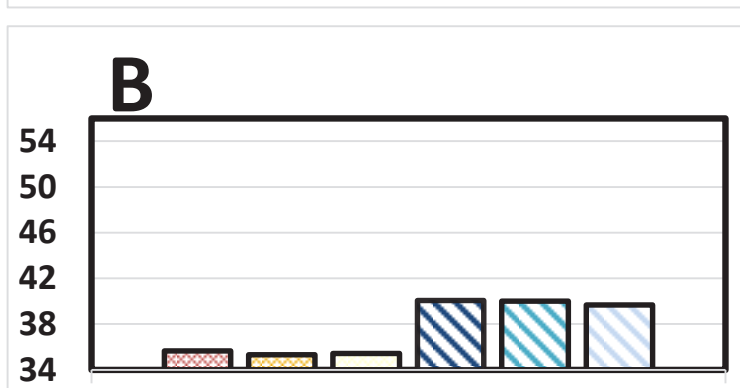

Average Ts at nighttime periods

$$
\begin{array}{lll}
\square T s(A N) & \square T s(A B) & \square T s(A G) \\
\nabla T s(D N) & \square T s(D B) & \square T s(D G)
\end{array}
$$
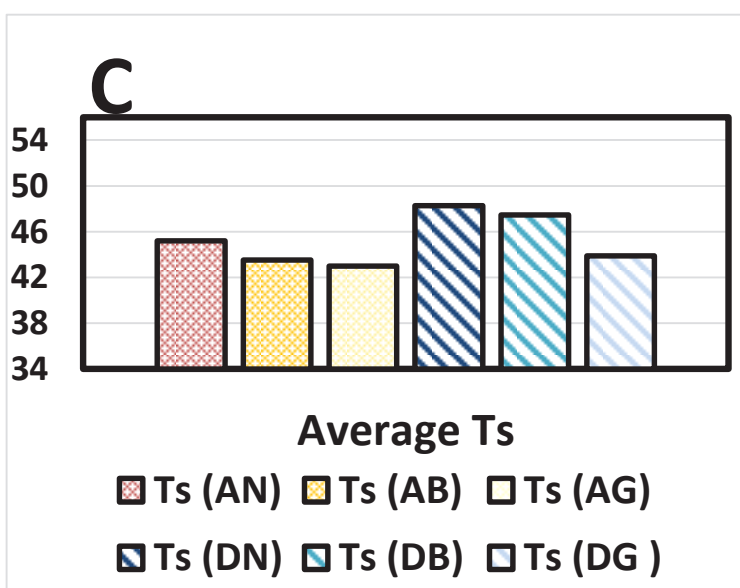

scenarios while it was $2.1^{\circ} \mathrm{C}$ between no green and green

Fig. 7. Average of $T_{s}$ at pedestrian walkway of each street. A) Represent average of total $T_{s}$ during the daytime periods; B) represent average of $T_{s}$ during the night time periods; C) represent average of total $T_{s}$ during the daytime and night time periods. 
scenarios. The difference in average during nighttime periods was $0.5^{\circ} \mathrm{C}$ between no green and base scenarios while it was $1.0^{\circ} \mathrm{C}$ between no green and green scenarios. The results have shown that the green area is more effective during daytime periods. The reason for this is the shade from trees which increases with increasing tree density and causes a reduction in values of $T_{m r t}$.

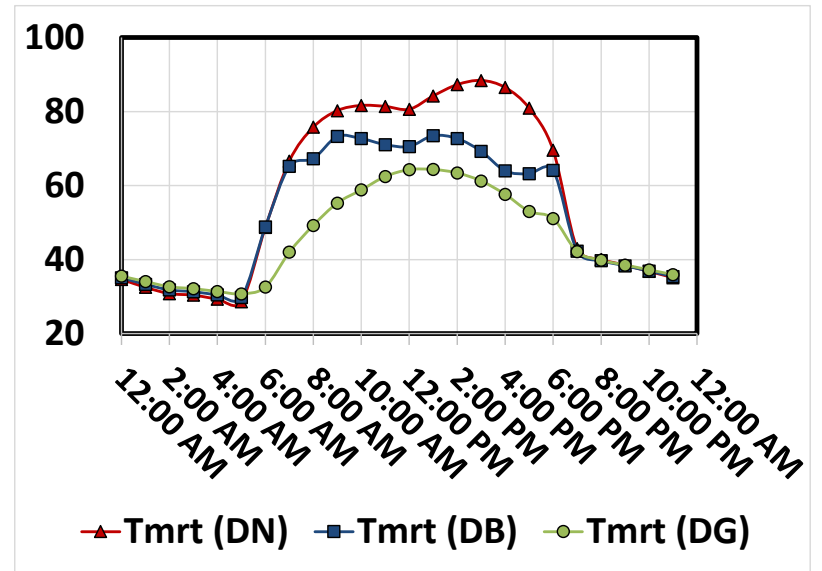

Fig. 8. Variations of $T_{m r t}$ during the day at pedestrian walkway of detached pattern at a height of $1.5 \mathrm{~m}$ from the ground.

In the attached pattern (Fig 9), the hottest values of $T_{m r t}$ was found at 3:00 PM which were $85.4^{\circ} \mathrm{C}, 72.5^{\circ} \mathrm{C}$ and $69.5^{\circ} \mathrm{C}$ in no green, base and green scenarios, respectively. The lowest values of $T_{m r t}$ was found at 5:00 AM which were $27.9^{\circ} \mathrm{C}, 29.2^{\circ} \mathrm{C}$ and $29.6^{\circ} \mathrm{C}$ in no green, base and green scenarios, respectively. The average values of $T_{m r t}$ were $53.4^{\circ} \mathrm{C}, 49.8^{\circ} \mathrm{C}$ and $48.0^{\circ} \mathrm{C}$ in no green, base and green scenarios, respectively. During daytime periods, the difference in average was $6.8^{\circ} \mathrm{C}$ between no green and base scenarios while it was $10.1^{\circ} \mathrm{C}$ between no green and green scenarios. During nighttime periods, the maximum difference in $T_{m r t}$ was found in 5:00 AM which was $1.3^{\circ} \mathrm{C}$ between no green and base scenarios while it was $1.7^{\circ} \mathrm{C}$ between no green and green scenarios. The difference in average at nighttime periods was $0.9^{\circ} \mathrm{C}$ between no green and base scenarios while it was $1.0^{\circ} \mathrm{C}$ between no green and green scenarios. The results have shown that the green area is more effective during daytime periods. The reason for this is the shade from trees which increases with increasing tree density and causes a reduction in values of $T_{m r t}$.

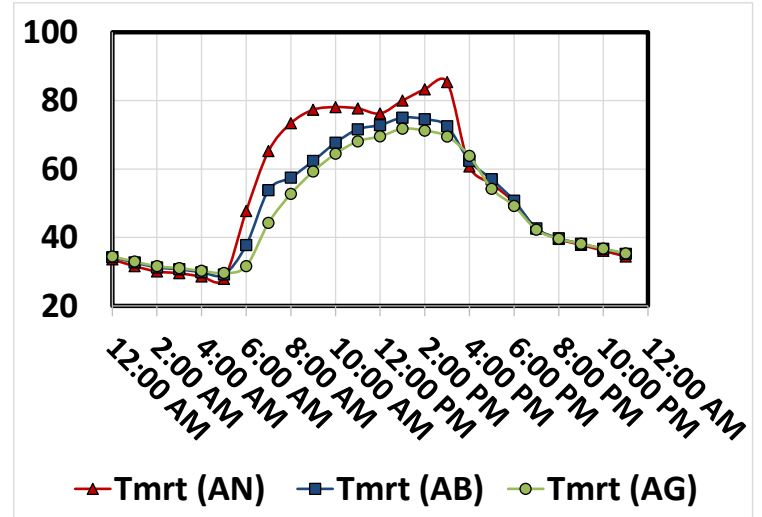

Fig. 9. Variations of $T_{m r t}$ during the day at pedestrian walkway of attached pattern at a height of $1.5 \mathrm{~m}$ from the ground.

Figure 10 compares between average values of $T_{m r t}$ in different scenarios. In no green scenarios, the results have shown that the detached pattern has higher value of $T_{m r t}$ than attached by $4.5^{\circ} \mathrm{C}$ on an average. The maximum difference in $T_{m r t}$ during daytime periods was found in 4:00 $\mathrm{PM}$ which was $25.8^{\circ} \mathrm{C}$. The difference on an average during daytime periods was $7.2^{\circ} \mathrm{C}$. During nighttime periods the two area have almost equal value of $T_{m r t}$. The maximum difference in $T_{m r t}$ during nighttime periods was found in 0:00 AM o'clock which was $1.1^{\circ} \mathrm{C}$. The average difference during nighttime periods was $0.8^{\circ} \mathrm{C}$.

In base scenarios, the results have shown that the detached pattern has higher value of $T_{m r t}$ than attached by $2.7^{\circ} \mathrm{C}$ on an average. The maximum difference in $T_{m r t}$ during daytime periods was found in 6:00 PM which was $13.4^{\circ} \mathrm{C}$. The difference on an average during daytime periods was $4.2^{\circ} \mathrm{C}$. During nighttime periods the two area have almost equal value of $T_{m r t}$. The maximum difference in $T_{m r t}$ during nighttime periods was found in 0:00 AM which was $0.9^{\circ} \mathrm{C}$. The difference on an average during nighttime periods was $0.5^{\circ} \mathrm{C}$. It is noticed that green area works to create a greater thermal balance between the two patterns.

In green scenarios, the results have shown that the detached pattern have lower value of $T_{m r t}$ than attached by $2.0^{\circ} \mathrm{C}$ on an average. The maximum difference in $T_{m r t}$ during daytime periods was found in 1:00 PM which was $7.4^{\circ} \mathrm{C}$. The difference on an average during daytime periods was $3.9^{\circ} \mathrm{C}$. During nighttime periods, the two area have almost equal value of $T_{m r t}$. The maximum difference in $T_{m r t}$ during nighttime periods was found in 0:00 AM which was $1.1^{\circ} \mathrm{C}$. The difference on an average during nighttime periods was $0.8^{\circ} \mathrm{C}$. It was noticed that the higher density of trees in the detached pedestrian walkway greatly reduce $T_{m r t}$ than the lower density of trees in the attached pedestrian walkway. 
The best scenario of $T_{m r t}$ in all cases was found in detached pattern with green scenario while the worst scenario of $T_{m r t}$ in all cases was found in detach area

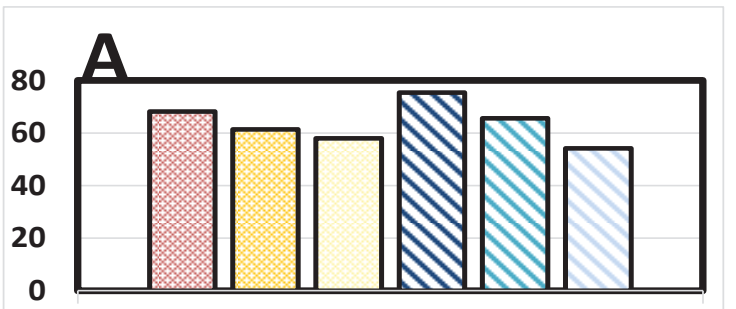

Average Tmrt at daytime periods

圆Tmrt (AN) $\square \operatorname{Tmrt}(\mathrm{AB}) \square \operatorname{Tmrt}(\mathrm{AG})$

$\nabla T m r t(D N) \square T m r t(D B) \square T m r t(D G)$

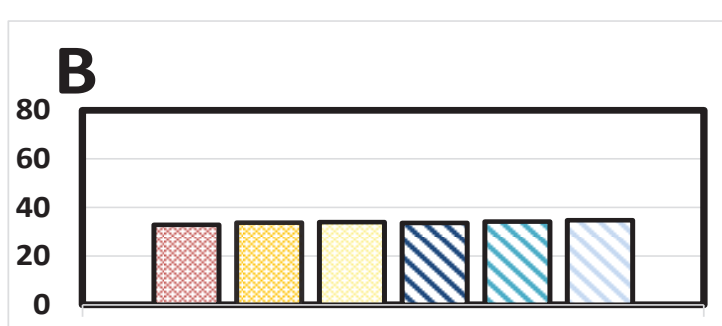

Average Tmrt at nighttime periods

口Tmrt (AN) $\square \operatorname{Tmrt}(\mathrm{AB}) \square \operatorname{Tmrt}(\mathrm{AG})$

$\nabla T m r t(D N) \square T m r t(D B) \square T m r t(D G)$

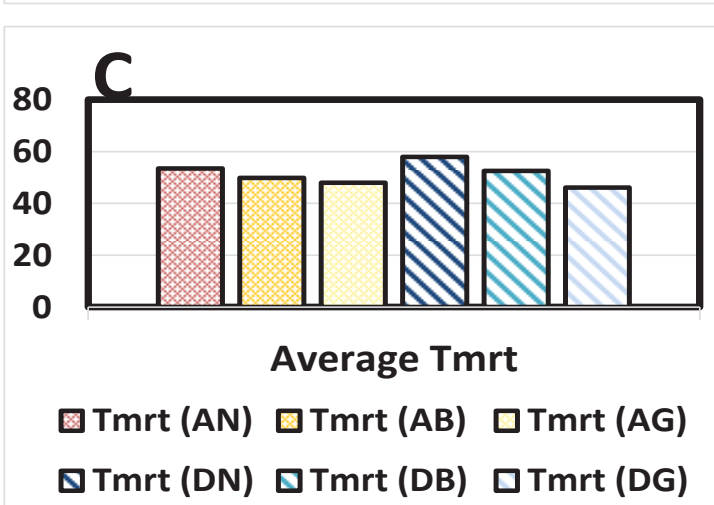

Fig. 10. Average of $T_{m r t}$ at pedestrian walkway of each street at $1.5 \mathrm{~m}$ height. A represent average of total $T_{m r t}$ during the daytime periods. B represent average of $T_{m r t}$ during the nighttime periods. C represent average of total $T_{m r t}$ during the daytime and nighttime periods

with no green scenario. The trees cover and its density played an important role in influencing the value of $T_{m r}$.

\section{Conclusions}

Simulation studies have been carried out for evaluating the effect of geometric properties of different patterns of urban canyons and green area on temperature distribution (ambient air temperature $\left(T_{a}\right)$, street surface temperature $\left(T_{s}\right)$ and mean radiant temperature $\left(T_{m r t}\right)$ in two locations in the city of Baghdad.

The study reached the following conclusions:

-First, at the pedestrian level scale, the urban geometry and green area contribute significantly to reduce of mean radiant temperature $\left(T_{m r t}\right)$ and street surface temperature $\left(T_{s}\right)$ values while there was no significant effect on the ambient air temperature $\left(T_{a}\right)$ values.

-Second, changes in the values of $T_{s}$ and $T_{m r t}$ were during daylight hours, while there was no significant effect during night time.

Accordingly, this study recommends reviewing the practices and standards of planning and urban design in the city of Baghdad, such as the height of the building or the distance between them, in accordance with the hot and dry extreme external microclimate conditions of the city. This can be achieved by providing the greatest amount of shading in the pedestrian walkway using the urban geometry or vegetation or both.

\section{References}

[1] T. R. Oke, "Urban climates and global environmental change," Applied Climatology: Principles \& Practices. New York, NY: Routledge, 1997, pp. 273-287.

[2] E. Johansson, "Influence of urban geometry on outdoor thermal comfort in a hot dry climate: A study in Fez, Morocco," Build. Environ., vol. 41, no. 10, pp. 1326-1338, 2006.

[3] S. Shooshtarian, "Urban heat island," pp. 4-6, 2014.

[4] Q. S. R. Alshammary, "The Role of Green Areas in the Environmental System Efficiency for the City," University of Technology, 2013.

[5] C. O’Malley, P. Piroozfar, E. R. P. Farr, and F. Pomponi, "Urban Heat Island (UHI) mitigating strategies: A case-based comparative analysis," Sustain. Cities Soc., vol. 19, no. August 2016, pp. 222-235, 2015.

[6] Y. Wang and H. Akbari, "Development and application of 'thermal radiative power' for urban environmental evaluation," Sustain. Cities Soc., vol. 14, pp. 316-322, 2015.

[7] Y. Wang, U. Berardi, and H. Akbari, "The Urban Heat Island Effect in the City of Toronto," Procedia Eng., vol. 118, pp. 137-144, 2015.

[8] M. Z. Targhi and S. Van Dessel, "Potential Contribution of Urban Developments to Outdoor Thermal Comfort Conditions: The Influence of Urban Geometry and Form in Worcester, Massachusetts, USA," Procedia Eng., vol. 118, pp. 1153-1161, 2015.

[9] A. Dimoudi and M. Nikolopoulou, "Vegetation in the Urban Environment," Energy Build., vol. 
35, pp. 69-76, 2003.

[10] Aws M. Salman and Younis M. Mohammed, "Impact of Microclimate Improvement Strategies on the Quality of External Spaces in Baghdad City," in Scientific Conference of the Ministry of Construction, Housing, Municipalities and Puplic works, 2017.

[11] T. R. Oke, Boundary layer climates. Routledge, London.

[12] H. Taha, S. Douglas, and J. Haney, "Mesoscale meteorological and air quality impacts of increased urban albedo and vegetation," Energy Build., vol. 25, no. 2, pp. 169-177, 1997.

[13] D. J. Sailor, "A review of methods for estimating anthropogenic heat and moisture emissions in the urban environment," Int. J. Climatol., vol. 31, no. 2, pp. 189-199, 2011.

[14] L. S. Pereira, A. Perrier, R. G. Allen, and A. and I. A. Member, "Evapotranspiration:concepts and future trends," no. APRIL, pp. 45-51, 1999.

[15] U. S. Epa, "Reducing Urban Heat Islands: Compendium of Strategies," Heat Isl. Reduct. Act., pp. 1-23, 2008.

[16] K. Perini and A. Magliocco, "Effects of vegetation, urban density, building height, and atmospheric conditions on local temperatures and thermal comfort," Urban For. Urban Green., vol. 13, no. 3, pp. 495-506, 2014.

[17] D. Alobaydi, H. Mohamed, and H. Attya, "The Impact of Urban Structure Changes on the Airflow Speed Circulation in Historic Karbala, Iraq," Procedia Eng., vol. 118, pp. 670-674, 2015.

[18] M. M. Elnahas, "Energy Simulation of Urban Dwellings i n Temperate Climates," no. June 2013, pp. 37-41, 2011.

[19] D. Robinson, "Urban morphology and indicators of radiation availability," Sol. Energy, vol. 80, no. 12, pp. 1643-1648, 2006.

[20] D. Alobaydi, M. A. Bakarman, and B. Obeidat, "The Impact of Urban Form Configuration on the Urban Heat Island: The Case Study of Baghdad, Iraq," Procedia Eng., vol. 145, pp. 820-827, 2016.

[21] The National Committee for Population Policies, "The Situation of Iraq 's Population in 2010, The first national report on the situation of the population as part of the recommendations of the Cairo Conference on Population and Development Goals," Cent. Stat. Organ. Minist. Plan., 2011.

[22] M. Bruse, "ENVI-met website," 2014. [Online]. Available: http://www.envi-met.com/.

[23] M. Bruse, "The influences of local environmental design on microclimate development of a prognostic numerical model ENVI-met for the simulation of Wind, temperature and humidity distribution in urban structures," University of Bochum 9, Germany, 1999.

[24] A. J. B. I. Ozkeresteci, K. Crewe, "Use and evaluation of the envi-met model for environmental design and planning : an experiment on linear parks," Proc. 21st Int. Cartogr. Conf., no. August, pp. 10-16, 2003.

[25] B. M. S. Alznafer, "The Impact of Neighbourhood Geometries on Outdoor Thermal Comfort and Energy Consumption From Urban Dwellings," 2014.

[26] H. Bruse, M., Fleer, Simulating surface-plantair interactions inside urban environments with a three dimensional numerical model. 1998. 